\title{
Kombinasi Jarak Tanam dan Dosis Pupuk (ZA dan KCI) Terhadap Pertumbuhan dan Hasil Benih F1 Varietas Bima 20
}

\author{
Combination of Plant Spacing and Fertilizer Doses (ZA and $\mathrm{KCl}$ ) on Growth \\ and Yield of F1 Bima 20 Variety
}

$$
\text { Author(s): Suwarti }{ }^{(1) * ;} \text { Suwardi }{ }^{(1)}
$$

(1) Balai Penelitian Tanaman Serealia

* Corresponding author: warti.smile@gmail.com

\begin{abstract}
ABSTRAK
Penggunaan dosis pupuk yang tepat dengan pengaturan jarak tanam legowo merupakan faktor yang diharapkan dapat meningkatkan pertumbuhan tanaman dan produktivitas benih jagung hibrida. Tujuan dari penelitian ini adalah untuk menguji model jarak tanam jajar legowo $((100 \mathrm{~cm}-50 \mathrm{~cm}) \times 20 \mathrm{~cm})$ dibandingkan dengan model jarak tanam normal $(75 \mathrm{~cm} \times 20 \mathrm{~cm})$ dengan kombinasi berbagai dosis pupuk terhadap tingkat produktivitas benih jagung hibrida Bima 20. Percobaan dilaksanakan di Kebun Percobaan Balitsereal Maros, pada bulan Mei sampai dengan Agustus 2017. Percobaan dilakukan menggunakan Rancangan petak tersarang (nested randomized block design). Empat perlakuan pemupukan yaitu A : $350 \mathrm{~kg} / \mathrm{ha} U$ rea $+50 \mathrm{~kg} / \mathrm{ha} \mathrm{KCl} ; \mathrm{B}: 350 \mathrm{~kg} / \mathrm{ha}$ Urea +100 $\mathrm{kg} / \mathrm{ha} \mathrm{KCl}$; $\mathrm{C}: 350 \mathrm{~kg} / \mathrm{ha}$ Urea $+50 \mathrm{~kg} / \mathrm{ha} \mathrm{ZA}$; D ; $350 \mathrm{~kg} / \mathrm{ha}$ Urea $+100 \mathrm{~kg} / \mathrm{ha}$ ZA diulang tiga kali pada dua perlakuan jarak tanam yaitu jarak tanam konvensional $70 \mathrm{~cm}$ x $20 \mathrm{~cm}$ dan jarak tanam jajar legowo $(100 \mathrm{~cm}-50 \mathrm{~cm}) \times 20 \mathrm{~cm}$. Pengamatan pertumbuhan dan hasil panen dilakukan terhadap tanaman betina. Interaksi antara perlakuan menunjukkan berbeda nyata pada lebar daun. Hasil panen tertinggi pada faktor tunggal pupuk diperoleh pada kombinasi pupuk $350 \mathrm{~kg} / \mathrm{ha}$ Urea $+50 \mathrm{~kg} / \mathrm{ha} \mathrm{Za} \mathrm{(10.62} \mathrm{ton/ha).} \mathrm{Model} \mathrm{jarak} \mathrm{tanam}$ jajar legowo secara mandiri menunjukkan hasil $9.66 \mathrm{t} / \mathrm{ha}$ lebih tinggi dibandingkan jarak tanam $75 \mathrm{~cm}$ x $20 \mathrm{~cm}$. Koefisien korelasi Pearson dengan hasil biji tertinggi diperoleh pada peubah panjang tongkol dan tinggi tanaman $(\mathrm{r}=0.40)$.
\end{abstract}

\section{Kata Kunci:}

Dosis pupuk;

Jarak tanam;

Pertumbuhan;

Produktivitas;

\section{Keywords:}

Fertilizer doses;

Plant Row;

Plant Growth; productivity;

\section{ABSTRACT}

Application of the precise fertilizer dose combined to appropriate planting spacing is a factor that is expected to increase plant growth and productivity of hybrid maize seeds. The purpose of this study was to examine the legowo row spacing model $((100 \mathrm{~cm}-50$ cm) $\times 20 \mathrm{~cm})$ compared to the normal spacing model $(75 \mathrm{~cm} \times 20 \mathrm{~cm})$ with a combination of various fertilizer doses to the productivity rate of Bima 20 hybrid maize seeds. The experiment was conducted at the ICERI Experimental Station Maros, from May to August 2017. The experiment was carried out using a nested randomized block design. Four fertilization treatments were A: $350 \mathrm{~kg} / \mathrm{ha}$ Urea + 50 kg/ha KCl; B: $350 \mathrm{~kg} / \mathrm{ha} \mathrm{Urea}$ $+100 \mathrm{~kg} / \mathrm{ha} \mathrm{KCl}$; C: $350 \mathrm{~kg} / \mathrm{ha}$ Urea $+50 \mathrm{~kg} / \mathrm{ha} \mathrm{ZA;} \mathrm{D;} 350 \mathrm{~kg} / \mathrm{ha}$ Urea $+100 \mathrm{~kg} / \mathrm{ha}$ $Z A$ was repeated three times in two spacing treatments, namely conventional $70 \mathrm{~cm} \times 20$ $\mathrm{cm}$ spacing and legowo row spacing $(100 \mathrm{~cm}-50 \mathrm{~cm}) \times 20 \mathrm{~cm}$. Observation of growth and yields were carried out on female plants. Interactions between treatments showed significantly different on leaf widths. The highest yield on a single factor of fertilizer was obtained at a combination of $350 \mathrm{~kg} / \mathrm{ha}$ Urea $+50 \mathrm{~kg} / \mathrm{ha}$ Za (produced 10.62 tons seeds per ha). The independent jajarlegowo spacing model factor produced 9.66 tons seeds per ha, higher than the $75 \mathrm{~cm} \times 20 \mathrm{~cm}$ row spacing. Higher Pearson's correlation with yield was obtained on plant height and ear length $(r=0.40)$. 


\section{PENDAHULUAN}

Jagung dibutuhkan sebagai bahan pakan ternak unggas dan ternak besar, selain juga merupakan bahan baku industri dan bahan makanan (Apriliana and Mustadjab, 2016). Data Kementrian Pertanian (2016) menunjukkan produksi nasional masih belum mencukupi seluruh kebutuhan jagung di Indonesia, sehingga perlu peningkatan produktivitas melalui intensifikasi maupun ekstensifikasi. Pendekatan budidaya untuk meningkatkan produktivitas jagung dilakukan dengan menerapkan pengelolaan tanaman secara terpadu, diantaranya adalah menanam varietas jagung yang memiliki potensi hasil tinggi (Erungan et al., 2012; Syuryawati and Faesal, 2016). Salah satu varietas jagung Balitbangtan yang banyak dipilih petani adalah hibrida silang tiga jalur Bima 20 (Kushartanti et al., 2019; Pratama et al., 2019). Kelebihan varietas hibrida silang tiga jalur adalah memiliki tingkat adaptasi yang luas dibandingkan dengan hibrida silang tunggal, sehingga bisa ditanam di berbagai variasi lingkungan (Sayo et al., 2017; Sesay et al., 2016).

Benih unggul merupakan faktor penting dalam produksi tanaman jagung hibrida (Koes and Rahmawati, 2009). Salah satu upaya yang dilakukan untuk meningkatkan produksi jagung adalah penggunaan benih bermutu dengan vigor yang baik (Pratama et al., 2019). Daya tumbuh benih merupakan salah satu faktor yang menjadi pertimbangan utama dalam pemilihan benih untuk memperoleh keuntungan yang optimal (Rahmawati and Saenong, 2010; Arief et al., 2013). Benih dengan daya tumbuh kurang dari 95-98\% berpengaruh terhadap penurunan populasi tanaman tiap hektarnya. Ketersediaan benih jagung berkualitas di pasaran terbatas, sehingga diperlukan upaya untuk meningkatkan jumlah benih bermutu (Sutoro, 2012).

Menurut Rahmawati and Saenong (2010) salah satu masalah yang dikeluhkan oleh produsen benih jagung hibrida adalah rendahnya produksi F1 yang dihasilkan yaitu 1,0-1,5 t/ha. Produktitas F1 jagung hibrida yang rendah memicu harga benih di pasaran menjadi tinggi sehingga diperlukan upaya peningkatan produksi untuk menekan harga tersebut. Jagung varietas Bima 20 merupakan jagung silang tiga jalur (STJ) yaitu persilangan antara tetua jantan (NEI 9008) dan tetua betina (G180 x Mr-14) yang cukup diminati di kalangan petani. Akselerasi produksi benih F1 dilakukan dengan meningkatkan populasi tanaman sekaligus meningkatkan daya dukung ekosistemnya dengan pemupukan yang lebih optimal.

Pengaturan jarak tanam yang tepat yang disesuaikan dengan komponen budidaya lainnya menetukan produktivitas tanaman budidaya (Ikhwani, 2014; Irwan et al., 2005). Model jarak tanam legowo pada budidaya jagung telah dipakai pada budidaya jagung konsumsi (Srihartanto et al., 2013; Erawati and Hipi, 2016), namun penggunaan model pertanaman jajar legowo dalam kegiatan produksi benih $\mathrm{F} 1$ hibrida masih jarang dipergunakan. Kombinasi perlakuan model jarak tanam dengan dosis pupuk yang tepat diharapkan dapat meningkatkan kualitas dan jumlah produksi biji benih jagung F1 hibrida. Tujuan penelitian adalah untuk mengetahui pengaruh sistem jarak tanam dan kombinasi pupuk terhadap pertumbuhan, hasil dan komponen hasil pada produksi benih F1 jagung hibrida Bima 20.

\section{METODOLOGI}

Penelitian dilaksanakan di Kebun Percobaan Maros pada bulan Mei sampai dengan Agustus 2017. Percobaan dilakukan menggunakan rancangan petak tersarang (nested randomized block design). Empat perlakuan pemupukan yaitu A : $350 \mathrm{~kg} / \mathrm{ha}$ Urea $+50 \mathrm{~kg} / \mathrm{ha} \mathrm{KCl}$; B: $350 \mathrm{~kg} / \mathrm{ha}$ Urea $+100 \mathrm{~kg} / \mathrm{ha} \mathrm{KCl}$; C : $350 \mathrm{~kg} / \mathrm{ha}$ Urea $+50 \mathrm{~kg} / \mathrm{ha} \mathrm{ZA}$; D ; 350 $\mathrm{kh} / \mathrm{ha}$ Urea $+100 \mathrm{~kg} / \mathrm{ha}$ ZA pada dua 
perlakuan jarak tanam yaitu jarak tanam normal $70 \mathrm{~cm} \times 20 \mathrm{~cm}$ dan jarak tanam legowo $(100 \mathrm{~cm}-50 \mathrm{~cm}) \times 20 \mathrm{~cm}$, masingmasing kombinasi perlakuan diulang tiga kali sehingga diperoleh 24 unit percobaan. Layout pengaturan jarak tanam ditampilkan pada Gambar 1.

$$
\begin{aligned}
& \begin{array}{|l|l|}
\hline \text { Baris tanaman betina } & \multicolumn{2}{c|}{\text { Baris tanaman jantan }} \\
\hline \text { Female plant row } & \text { Male plant row } \\
\hline
\end{array}
\end{aligned}
$$

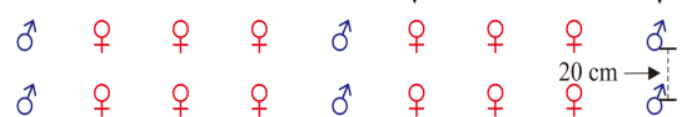

$$
\begin{aligned}
& \begin{array}{lllllllll} 
& 0 & + & + & 0 & \phi & + & + & 0
\end{array}
\end{aligned}
$$

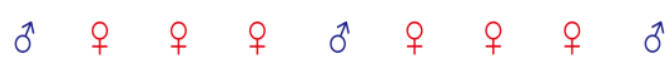

$$
\begin{aligned}
& \begin{array}{lllllllll} 
& 0 & + & + & \pi & + & + & + & 0
\end{array}
\end{aligned}
$$

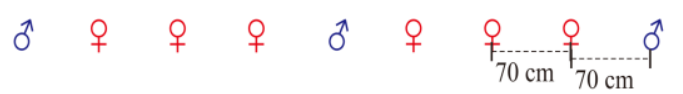

Jarak Tanam Normal $(70 \mathrm{~cm}$ x $20 \mathrm{~cm})$ Normal plant row $(70 \mathrm{~cm} \times 20 \mathrm{~cm})$

\begin{tabular}{|c|c|c|c|c|c|c|}
\hline & & Baris & man betina & & tanamar & \\
\hline & & & 1 & & & \\
\hline$\sigma^{\lambda}$ & o & 우 & o & 우 & 우 & $\hat{\sigma}_{T}$ \\
\hline$\sigma^{2}$ & 우 & 우 & 수 우 & 우 & & $\overrightarrow{d^{1}}$ \\
\hline$\sigma^{\lambda}$ & ㅇ & q & o & ㅇ & q & $\sigma^{\lambda}$ \\
\hline$\sigma^{\lambda}$ & q & 우 & o & 우 & 우 & $0^{\pi}$ \\
\hline$\sigma^{\pi}$ & 우 & 우 & 수 우 & 우 & 우 & $0^{\star}$ \\
\hline 0 & ㅇ & o & $\begin{array}{l}0 \quad+ \\
01 \\
50 \mathrm{~cm}\end{array}$ & 우 & $\stackrel{9}{+}$ & $0_{-1}^{\pi}$ \\
\hline
\end{tabular}

Gambar 1. Model pengaturan jarak tanam pada perlakuan normal dan legowo Figure 1. Plant row arrangement on normal and legowo treatment

Benih jagung ditanam satu biji dalam satu lubang dengan komposisi 3 baris tanaman jagung tetua betina (persilangan G180 x MR14) dan satu baris tanaman jagung tetua jantan (NEI 9008) pada baris tanaman sepanjang $6 \mathrm{~m}$. Pupuk dasar diberikan pada umur tanaman 10 hst (hari setelah tanam) dengan memberikan sepertiga dosis urea + seluruh pupuk ZA dan $\mathrm{KCl}$ sesuai perlakuan. Sisa dua per tiga pupuk urea diaplikasikan pada 30 hst. Tanaman tetua jantan (NEI 9008) ditanam 3 hari sebelum tanam tetua betina (G $180 \mathrm{x}$ MR 14)yang bertujuan untuk menyesuaikan waktu keluarnya malai tetua jantan (anthesis) bersamaan keluarnya rambut tetua betina (silking), sehingga terjadi sinkronisasi penyerbukan. Penanaman produksi benih dilakukan dengan memperhatikan isolasi waktu (21 hari) atau isolasi jarak $(200 \mathrm{~m})$ dengan tanaman jagung varietas lain, untuk menjaga dari kontaminasi serbuk sari. Pencabutan bunga jantan (detasselling) pada barisan tanaman betina dilakukan sebelum bunga jantan (anther) muncul, yaitu pada saat daun terakhir masih menggulung atau sedikit daun terbuka setiap 1-2 hari. Detasselling dilakukan pada umur tanaman 45-56 hst tanaman betina tergantung kondisi lingkungan cuaca di pertanaman.

Pengamatan dilakukan untuk mengumpulkan data karakter agronomis, hasil dan komponen hasil jagung tetua betina. Data hasil pengamatan diolah secara statistik menggunakan Analysis of Variance (ANOVA). Apabila peubah amatan menunjukkan hasil berbeda nyata maka dilanjutkan dengan uji Duncan Multiple Range Test (DMRT) pada taraf kesalahan 5\%. Uji korelasi dilakukan untuk melihat keterkaitan antar peubah pengamatan dengan produktivitas.

\section{HASIL DAN PEMBAHASAN}

Kondisi iklim di lokasi penelitian selama masa percobaan ditampilkan pada Tabel 1. Jumlah hari hujan pada saat penelitian dilaksanakan, berkisar antara 9 hingga 14 hari per bulan. Jumlah curah hujan tertinggi terjadi pada bulan Juni, atau 
saat tanaman pada fase vegetatif awal. Kekurangan air pada berbagai fase pertumbuhan tanaman jagung mengakibatkan pertumbuhan tanaman, luas daun, kehijauan tanaman dan persentase tanaman fertile mengalami penurunan (Efendi and Azrai, 2010). Curah hujan pada bulan Juli sudah menurun dari bulan Juni menjadi $44.70 \mathrm{~mm}$, saat tanaman jagung di percobaan ini pada fase pembungaan.

Tabel 1. Kondisi iklim di lokasi percobaan, Kebun Percobaan Balitsereal Maros, 2017

Table 1. Climatic conditions at the experiment site, ICERI Experimental Station Maros, 2017

\begin{tabular}{|c|c|c|c|c|c|}
\hline \multirow{2}{*}{$\begin{array}{l}\text { Kondisi Iklim } \\
\text { Climate condition }\end{array}$} & \multicolumn{5}{|c|}{ Bulan (Month) } \\
\hline & $\begin{array}{l}\text { Mei } \\
\text { May }\end{array}$ & $\begin{array}{l}\text { Juni } \\
\text { June }\end{array}$ & $\begin{array}{l}\text { Juli } \\
\text { July }\end{array}$ & $\begin{array}{l}\text { Agustus } \\
\text { August }\end{array}$ & $\begin{array}{l}\text { September } \\
\text { September }\end{array}$ \\
\hline $\begin{array}{l}\text { Rata-rata suhu minimum }\left({ }^{\circ} \mathrm{C}\right) \\
\text { Average minimum temperature }\left({ }^{\circ} \mathrm{C}\right)\end{array}$ & 24.92 & 24.23 & 23.75 & 23.79 & 24.45 \\
\hline $\begin{array}{l}\text { Rata-rata suhu maksimum }\left({ }^{\circ} \mathrm{C}\right) \\
\text { Average aximum temperature }\left({ }^{\circ} \mathrm{C}\right)\end{array}$ & 31.61 & 30.79 & 31.11 & 32.48 & 33.25 \\
\hline $\begin{array}{l}\text { Suhu rata-rata }\left({ }^{\circ} \mathrm{C}\right) \\
\text { Temperature average }\left({ }^{\circ} \mathrm{C}\right)\end{array}$ & 27.59 & 26.76 & 26.79 & 27.58 & 28.32 \\
\hline $\begin{array}{l}\text { Kelembaban rata-rata }(\%) \\
\text { Average humidity }\left({ }^{\circ} \mathrm{C}\right)\end{array}$ & 83.32 & 84.90 & 81.42 & 70.76 & 70.55 \\
\hline $\begin{array}{l}\text { Curah hujan (mm) } \\
\text { Rainfall (mm) }\end{array}$ & 85.70 & 158.90 & 44.70 & 27.20 & 94.20 \\
\hline $\begin{array}{l}\text { Lamanya penyinaran matahari (jam) } \\
\text { Solar radiation duration (hour) }\end{array}$ & 6.16 & 4.77 & 6.06 & 8.51 & 8.77 \\
\hline $\begin{array}{l}\text { Jumlah hari hujan } \\
\text { Number of days rain }\end{array}$ & 12 & 14 & 14 & 11 & 9 \\
\hline
\end{tabular}

Sumber data: Stasiun Klimatologi Maros yang diunduh dari situs (BMKG, 2018)

Data sources: Maros Meteorogical, Climatological and Geophysical Agency Station (BMKG, 2018)

Curah hujan yang rendah mendukung peluang terjadinya penyerbukan yang lebih baik, namun tanaman harus kecukupan air pada saat proses penyerbukan terjadi. Kekurangan air pada saat fase penyerbukan dapat mengakibatkan gagalnya pengisian biji atau ukuran biji menjadi lebih kecil (Sirappa and Razak, 2010). Kabupaten Maros masuk ke dalam tipe iklim C3 yang memiliki curah hujan 2000 sampai dengan $2500 \mathrm{~mm}$ per tahun. Kelembaban rata-rata tertinggi terjadi pada bulan Juni yaitu $84.90 \%$. Lamanya penyinaran matahari berkisar 4.77 jam per hari pada saat banyak hujan di bulan Juni hingga 8.51 jam per hari pada bulan Agustus.
Hasil analisis sidik ragam seluruh peubah pengamatan ditampilkan pada Tabel 2. Hasil tersebut menunjukkan interaksi antara perlakuan jarak tanam dan komposisi pupuk hanya berpengaruh nyata terhadap peubah pengamatan lebar daun. Faktor tunggal komposisi pupuk memberikan pengaruh sangat nyata pada hasil panen dan nyata pada peubah diameter tongkol. Perlakuan pengaturan jarak tanam memberikan pengaruh sangat nyata pada produksi, diameter tongkol, tinggi tongkol, panjang daun dan lebar daun. Pengaruh nyata perlakuan jarak tanam diperoleh pada peubah panjang tongkol, jumlah biji per baris, bobot 100 biji dan tinggi tanaman, dan jumlah biji per 
tongkol. Sedangkan pada peubah jumlah baris biji per tongkol menunjukkan hasil tidak nyata.

Perlakuan tunggal dosis pupuk 350 $\mathrm{kg} / \mathrm{ha}$ Urea $+50 \mathrm{~kg} / \mathrm{ha} \mathrm{Za}$ dan dosis pupuk $350 \mathrm{~kg} / \mathrm{ha}$ Urea $+100 \mathrm{~kg} / \mathrm{ha} \mathrm{Za}$ menghasilkan bobot panen biji per hektar yang lebih tinggi dibandingkan pada perlakuan dosis pupuk $350 \mathrm{~kg} / \mathrm{ha}$ Urea +50 $\mathrm{kg} / \mathrm{ha} \mathrm{KCl}$ dan dosis pupuk $350 \mathrm{~kg} / \mathrm{ha}$ Urea
$+100 \mathrm{~kg} / \mathrm{ha} \mathrm{KCl}$. Pemberian pupuk ZA yang dikombinasikan dengan Urea lebih efektif meningkatkan hasil panen benih jagung hibrida Bima 20 dibandingkan pemberian pupuk urea kombinasi dengan $\mathrm{KCl}$. Nitrogen dan air merupakan factor pembatas yang paling mempengaruhi hasil jagung, sehingga pemberian unsure $\mathrm{N}$ yang cukup akan meningkatkan hasil (Moser et al., 2006).

Tabel 2. Rangkuman Sidik Ragam Pengamatan Hasil, Komponen Hasil dan Karakter Agronomis pada Percobaan Pengaturan Jarak Tanam dan Dosis Pupuk, 2017

Table 2. ANOVA summary of yield, yield components and agronomic characters on the combination of plant row and fertilizer dosage experiment, 2017

\begin{tabular}{|c|c|c|c|c|c|c|}
\hline $\begin{array}{l}\text { Sumber Keragaman } \\
\text { Source }\end{array}$ & JT & $\mathrm{U}(\mathrm{JT})$ & $\mathrm{P}$ & $\mathrm{JT} * \mathrm{P}$ & Rata- & KK \\
\hline $\begin{array}{l}\text { Derajat bebas } \\
\text { Degree of freedom }\end{array}$ & 1 & 4 & 3 & 3 & $\begin{array}{c}\text { rata } \\
\text { Mean }\end{array}$ & $C V$ \\
\hline $\begin{array}{l}\text { Produktivitas } \\
\text { Yield }\end{array}$ & $6.81 * *$ & $0.33 \mathrm{~ns}$ & $16.82 * *$ & $0.69 \mathrm{~ns}$ & 9.12 & 7.66 \\
\hline $\begin{array}{l}\text { Panjang tongkol } \\
\text { Ear length }\end{array}$ & $4.77^{*}$ & $0.47 \mathrm{~ns}$ & $1.07 \mathrm{~ns}$ & $0.07 \mathrm{~ns}$ & 19.06 & 4.27 \\
\hline $\begin{array}{l}\text { Diameter tongkol } \\
\text { Ear diameter }\end{array}$ & $2.16^{* *}$ & $0.00 \mathrm{~ns}$ & $0.05 *$ & $0.02 \mathrm{~ns}$ & 4.93 & 2.19 \\
\hline $\begin{array}{l}\text { Jumlah Baris } \\
\text { Kernels row number }\end{array}$ & $0.00 \mathrm{~ns}$ & $0.24 \mathrm{~ns}$ & $0.70 \mathrm{~ns}$ & $0.20 \mathrm{~ns}$ & 12.64 & 5.74 \\
\hline $\begin{array}{l}\text { Jumlah biji per baris } \\
\text { Kernels number per row }\end{array}$ & $22.04 *$ & $2.31 \mathrm{~ns}$ & $2.41 \mathrm{~ns}$ & $3.39 \mathrm{~ns}$ & 32.40 & 5.35 \\
\hline $\begin{array}{l}\text { Bobot } 100 \text { biji } \\
100 \text { seeds weight }\end{array}$ & $105.84^{*}$ & $0.79 \mathrm{~ns}$ & $30.16 \mathrm{~ns}$ & $7.87 \mathrm{~ns}$ & 46.49 & 9.67 \\
\hline $\begin{array}{l}\text { Tinggi tanaman } \\
\text { Plant height }\end{array}$ & $477.04 *$ & $138.79 \mathrm{~ns}$ & $95.79 \mathrm{~ns}$ & $31.95 \mathrm{~ns}$ & 186.42 & 4.64 \\
\hline $\begin{array}{l}\text { Tinggi tongkol } \\
\text { Ear stand height }\end{array}$ & $213.01 * *$ & $17.18 \mathrm{~ns}$ & $28.16 \mathrm{~ns}$ & $25.15 \mathrm{~ns}$ & 93.41 & 5.07 \\
\hline $\begin{array}{l}\text { Panjang daun } \\
\text { Leaf length }\end{array}$ & $67.77^{* *}$ & $3.35 \mathrm{~ns}$ & $7.75 \mathrm{~ns}$ & $22.34 \mathrm{~ns}$ & 100.82 & 2.52 \\
\hline $\begin{array}{l}\text { Lebar daun } \\
\text { Leaf width }\end{array}$ & $1.93^{* *}$ & $0.18 \mathrm{~ns}$ & $0.18 \mathrm{~ns}$ & $1.25 * *$ & 10.66 & 3.69 \\
\hline $\begin{array}{l}\text { Jumlah biji per tongkol } \\
\text { Kernels number per ear }\end{array}$ & $3616.46^{*}$ & $1306.82 \mathrm{~ns}$ & $2013.59 \mathrm{~ns}$ & $741.65 \mathrm{~ns}$ & 409.52 & 6.10 \\
\hline
\end{tabular}

Keterangan : JT = Jarak tanam; U=ulangan; $\mathrm{P}=$ Pengaturan dosis dan kombinasi pupuk; KK = Koefisien Keragaman; "“*”=berbeda sangat nyata; "**"=berbeda nyata; "ns"=berbeda tidak nyata pada taraf kepercayaan $95 \%$.

Note : JT=Plant row; $U=$ replication; $P=$ dosage and combination of fertilizer treatment; $C V=C o e f f i c i e n t$ of variance; "**"=highly significantly different; "*"=significantly different; "tn" = non significantly different at the $95 \%$ level of confidence. 
Penambahan pupuk ZA $100 \mathrm{~kg} / \mathrm{ha}$ memberikan hasil 10.51 ton/ha, hasil ini sedikit lebih rendah dibandingkan pemberian ZA dengan dosis $50 \mathrm{~kg}(10.62$ ton/ha) meskipun secara statistik tidak berbeda. Pupuk ZA memiliki harga yang lebih murah dibandingkan urea, meskipun memiliki kandungan Nitrogen setengah dari kandungan pada pupuk Urea. Jika penggunaan pupuk ZA $50 \mathrm{~kg} / \mathrm{ha}$ dapat meningkatkan hasil panen jagung, maka dapat direkomendasikan untuk menghemat biaya pupuk. Hasil panen yang tinggi pada kombinasi pupuk $350 \mathrm{~kg} / \mathrm{ha}$ Urea+ 50 $\mathrm{kg} / \mathrm{ha}$ Za didukung diameter tongkol yang lebih besar $(5.03 \mathrm{~cm})$ pada kombinasi pupuk $350 \mathrm{~kg} / \mathrm{ha}$ Urea $+50 \mathrm{~kg} / \mathrm{ha} \mathrm{Za}$. Produktivitas tanaman jagung sangat dipengaruhi oleh kesuburan tanah, unsur hara $\mathrm{N}$ terhadap produksi memberikan kontribusi sebesar 30-50\% (Syafruddin, 2016).

Tabel 3. Pengaruh Tunggal Perlakuan Komposisi Pupuk pada Peubah Hasil dan Komponen Hasil

Table 3.Single effect of fertilizer composition treatment on yield variables and yield components

\begin{tabular}{|c|c|c|c|c|c|c|}
\hline $\begin{array}{c}\text { Komposisi Pupuk } \\
\text { Fertilizer composition }\end{array}$ & $\begin{array}{c}\text { Produktivitas } \\
\text { Yield }\end{array}$ & $\begin{array}{c}\text { Panjang } \\
\text { Tongkol } \\
\text { Ear length }\end{array}$ & $\begin{array}{c}\text { Dimeter } \\
\text { Tongkol } \\
\text { Ear } \\
\text { diameter }\end{array}$ & $\begin{array}{c}\text { Jumlah } \\
\text { Baris } \\
\text { Kernels } \\
\text { number per }\end{array}$ & $\begin{array}{c}\text { Jumlah Biji } \\
\text { per Baris } \\
\text { Kernels } \\
\text { rumber per }\end{array}$ & $\begin{array}{c}\text { Bobot } 100 \\
\text { Biji } \\
100 \text { seeds } \\
\text { weight }\end{array}$ \\
\hline & & & & ear & row & \\
\hline $\mathrm{U}+50 \mathrm{~kg} / \mathrm{ha} \mathrm{KCl}$ & $7.44 \mathrm{~b}$ & 19.23 & $4.83 \mathrm{~b}$ & 12.50 & 31.63 & 45.64 \\
\hline $\mathrm{U}+100 \mathrm{~kg} / \mathrm{ha} \mathrm{KCl}$ & $7.93 b$ & 18.43 & $4.98 \mathrm{ab}$ & 13.12 & 33.05 & 47.67 \\
\hline $\mathrm{U}+50 \mathrm{~kg} / \mathrm{ha} \mathrm{Za}$ & $10.62 \mathrm{a}$ & 19.33 & $5.03 \mathrm{a}$ & 12.62 & 32.77 & 48.86 \\
\hline $\mathrm{U}+100 \mathrm{~kg} / \mathrm{ha} \mathrm{Za}$ & $10.51 \mathrm{a}$ & 19.25 & $4.88 \mathrm{ab}$ & 12.32 & 32.15 & 43.78 \\
\hline
\end{tabular}

Keterangan $\quad: U=350 \mathrm{~kg} / \mathrm{ha}$ Urea. Huruf yang sama pada kolom yang sama menunjukkan tidak berbeda berdasarkan uji Tukey pada taraf kepercayaan $95 \%$

Note $\quad: U=350 \mathrm{~kg} / \mathrm{ha}$ Urea. The same letter in the same column means no different based on the Tukey test at the $95 \%$ confidence level

Tabel 4. Pengaruh Tunggal Perlakuan Komposisi Pupuk pada Peubah Komponen Agronomis dan Jumlah Biji per Tongkol

Table 4. Single effect of fertilizer composition treatment on agronomic component variables and number of seeds per ear

\begin{tabular}{lllccc}
\hline \multicolumn{1}{c}{ Komposisi Pupuk } & $\begin{array}{c}\text { Tinggi } \\
\text { Tanaman }\end{array}$ & $\begin{array}{c}\text { Tinggi } \\
\text { Tongkol }\end{array}$ & $\begin{array}{c}\text { Panjang } \\
\text { Daun }\end{array}$ & $\begin{array}{c}\text { Lebar } \\
\text { Daun }\end{array}$ & $\begin{array}{c}\text { Jumlah Biji } \\
\text { per Tongkol }\end{array}$ \\
\hline $\mathrm{U}+50 \mathrm{~kg} / \mathrm{ha} \mathrm{KCl}$ & 182.42 & 90.31 & 100.00 & 10.65 & 395.25 \\
$\mathrm{U}+100 \mathrm{~kg} / \mathrm{ha} \mathrm{KCl}$ & 184.00 & 95.03 & 100.30 & 10.62 & 433.98 \\
$\mathrm{U}+50 \mathrm{~kg} / \mathrm{ha} \mathrm{Za}$ & 191.28 & 93.56 & 100.47 & 10.90 & 413.17 \\
$\mathrm{U}+100 \mathrm{~kg} / \mathrm{ha} \mathrm{Za}$ & 187.97 & 94.75 & 102.50 & 10.48 & 395.69 \\
\hline
\end{tabular}

Keterangan : $U=350 \mathrm{~kg} / \mathrm{ha}$ Urea. Huruf yang sama pada kolom yang sama menunjukkan tidak berbeda berdasarkan uji tukey pada taraf kepercayaan $95 \%$.

Note $\quad: U=350 \mathrm{~kg} / \mathrm{ha}$ Urea. The same letter in the same column means no different based on the Tukey test at the $95 \%$ confidence level 
Tabel 5 menunjukkan interaksi antara perlakuan dosis pupuk dan model jarak tanam sangat nyata pada peubah lebar daun, hasil tertinggi diperoleh pada kombinasi jajar legowo dengan $350 \mathrm{~kg} / \mathrm{ha}$ Urea $+100 \mathrm{~kg} / \mathrm{ha} \mathrm{KCl}\left(11.39 \mathrm{~cm}^{2}\right)$ dan jajar legowo dengan $350 \mathrm{~kg} / \mathrm{ha}$ Urea $+50 \mathrm{~kg} / \mathrm{ha}$ $\mathrm{Za}\left(11.30 \mathrm{~cm}^{2}\right)$. Hasil ini sesuai dengan hasil penelitian Rahmansyah (2018) yang menunjukkan luas daun jagung pada pertanaman dengan pola jajar legowo lebih luas daripada jarak tanam konvensional. Kecukupan unsur hara dengan pemberian pupuk yang optimal, didukung oleh penetrasi sinar matahari yang lebih banyak pada pola jajar legowo akan meningkatkan proses metabolisme tanaman sehingga hasil fotosintat yang diperoleh juga lebih banyak sehingga pertumbuhan vegetatif tanaman jagung lebih baik.

Tabel 5. Pengaruh Interaksi Perlakuan Jarak Tanam dengan Komposisi Pupuk Terhadap Peubah Lebar Daun pada Tetua Betina Produksi Benih Jagung Hibrida Bima 20

Table 5. Effect of interaction between plant row arrangement and fertilizer composition treatment on leaf width variable in female parent plant of Bima 20 maize seed production

\begin{tabular}{llc}
\hline \multicolumn{1}{c}{$\begin{array}{c}\text { Perlakuan Jarak Tanam } \\
\text { Plant rows arrangement }\end{array}$} & \multicolumn{1}{c}{$\begin{array}{c}\text { Perlakuan Pupuk } \\
\text { Fertilizer dose }\end{array}$} & $\begin{array}{c}\text { Lebar Daun }\left(\mathrm{cm}^{2}\right) \\
\text { Leaf wide }\left(\mathrm{cm}^{2}\right)\end{array}$ \\
\hline Jarak TanamLegowo $(100$ & $350 \mathrm{~kg} / \mathrm{ha}$ Urea $+50 \mathrm{~kg} / \mathrm{ha} \mathrm{KCl}$ & $10.97 \mathrm{ab}$ \\
$\mathrm{cm}-50 \mathrm{~cm}) \times 20 \mathrm{~cm}$ & $350 \mathrm{~kg} / \mathrm{ha} \mathrm{Urea}+100 \mathrm{~kg} / \mathrm{ha} \mathrm{KCl}$ & $11.30 \mathrm{a}$ \\
Legowo rows arrangement & $350 \mathrm{~kg} / \mathrm{ha}$ Urea $+50 \mathrm{~kg} / \mathrm{ha} \mathrm{Za}$ & $11.39 \mathrm{a}$ \\
& $350 \mathrm{~kg} / \mathrm{ha} \mathrm{Urea}+100 \mathrm{~kg} / \mathrm{ha} \mathrm{Za}$ & $10.12 \mathrm{~b}$ \\
\hline Jarak TanamNormal & $350 \mathrm{~kg} / \mathrm{ha}$ Urea $+50 \mathrm{~kg} / \mathrm{ha} \mathrm{KCl}$ & $10.33 \mathrm{ab}$ \\
$(75 \mathrm{~cm} 20 \mathrm{~cm})$ & $350 \mathrm{~kg} / \mathrm{ha}$ Urea $+100 \mathrm{~kg} / \mathrm{ha} \mathrm{KCl}$ & $9.93 \mathrm{~b}$ \\
Normal rows arrangement & $350 \mathrm{~kg} / \mathrm{ha} \mathrm{Urea}+50 \mathrm{~kg} / \mathrm{ha} \mathrm{Za}$ & $10.41 \mathrm{ab}$ \\
& $350 \mathrm{~kg} /$ ha Urea $+100 \mathrm{~kg} / \mathrm{ha} \mathrm{Za}$ & $10.85 \mathrm{ab}$ \\
\hline
\end{tabular}

Keterangan : Huruf yang sama pada kolom yang sama menunjukkan tidak berbeda berdasarkan uji Tukey pada taraf kepercayaan $95 \%$.

Note $\quad: U=350 \mathrm{~kg} / \mathrm{ha}$ Urea. The same letter in the same column means no different based on the Tukey test at the $95 \%$ confidence level

Perlakuan jarak tanam legowo memberikan hasil yang lebih tinggi pada peubah bobot panen $(9.66$ ton/ha), panjang tongkol $(19.51 \mathrm{~cm})$, diameter tongkol $(5.23$ $\mathrm{cm})$ dan bobot 100 biji $(48.59 \mathrm{~g})$ dibandingkan perlakuan jarak tanam konvensional. Pada peubah pengamatan agronomis tinggi tanaman $(190.88 \mathrm{~cm})$, tinggi tongkol $(96.39 \mathrm{~cm})$, panjang daun $(102.50 \mathrm{~cm})$, lebar daun $(10.95 \mathrm{~cm})$ perlakuan jarak tanam legowo juga memberikan hasil yang lebih tinggi dibandingkan perlakuan jarak tanam konvensional (Tabel 6). Hasil penelitian lain pada pertanaman jagung hibrida varietas Bima 20 menunjukkan hal yang berbeda dari penelitian ini, yaitu perlakuan legowo menghasilkan pertumbuhan tinggi tanaman dan tinggi tongkol jagung yang cenderung lebih pendek dibandingkan dengan jarak tanam konvensional. Namun peningkatan produktivitas terjadi secara signifikan sesuai dengan hasil penelitian ini (Erawati and Hipi, 2016). Model jarak tanam jajar legowo memiliki lorong antar barisan yang lebih lebar, sehingga penetrasi sinar matahari lebih banyak untuk mendukung proses fotosintesis yang lebih optimal. Hal ini menyebabkan, meskipun jumlah biji per tongkol pada perlakuan jarak tanam $75 \mathrm{~cm}$ x $20 \mathrm{~cm}$ menunjukkan hasil rata-rata lebih banyak (421.80 butir), namun bobot 100 biji (44.39 g) lebih rendah dibandingkan bobot 100 
biji pada legowo yang menghasilkan jumlah biji rata-rata per tongkol 397.25 butir. Jumlah biji yang terbentuk dalam setiap tongkol jagung menunjukkan penyerbukan yang lebih baik, sedangkan bobot biji merupakan indikasi bahwa transfer fotosintat dalam proses fotosintesis tanaman terkonsentrasi untuk pembentukan biji (Syafrudin et al., 2016).

Tabel 6. Rata-rata Panjang Tongkol, Diameter Tongkol, Jumlah Baris per Tongkol, Jumlah Biji per Baris dan Bobot 100 Biji.

Table 6. Mean of ear length, ear diameter, kernels number per ear, kernels number per ear, kernels number per row and 100 seeds weight

\begin{tabular}{|c|c|c|c|c|c|c|}
\hline $\begin{array}{c}\text { Jarak Tanam } \\
\text { Plant rows arrangement }\end{array}$ & $\begin{array}{l}\text { Hasil (t/ha) } \\
\text { Yield (t/ha) }\end{array}$ & $\begin{array}{l}\text { Panjang } \\
\text { Tongkol } \\
(\mathrm{cm}) \\
\text { Ear length }\end{array}$ & $\begin{array}{c}\text { Dimeter } \\
\text { Tongkol } \\
(\mathrm{cm}) \\
\text { Ear } \\
\text { diameter }\end{array}$ & $\begin{array}{c}\text { Jumlah } \\
\text { Baris } \\
\text { Kernels } \\
\text { row } \\
\text { number pe } \\
\text { ear }\end{array}$ & $\begin{array}{l}\text { Jumlah Biji } \\
\text { per Baris } \\
\text { Kernels } \\
\text { number per } \\
\text { rrow }\end{array}$ & $\begin{array}{c}\text { Bobot } 100 \\
\text { Biji (g) } \\
100 \text { seeds } \\
\text { weight }\end{array}$ \\
\hline Legowo & $9.66 \mathrm{a}$ & $19.51 \mathrm{a}$ & $5.23 \mathrm{a}$ & $12.64 \mathrm{a}$ & $31.44 b$ & $48.59 \mathrm{a}$ \\
\hline Normal & $8.59 b$ & $18.62 \mathrm{~b}$ & $4.63 b$ & $12.63 \mathrm{a}$ & $33.36 \mathrm{a}$ & $44.39 b$ \\
\hline
\end{tabular}

Keterangan:

Jarak tanam legowo $=(100 \mathrm{~cm}-50 \mathrm{~cm}) * 20 \mathrm{~cm}$; jarak tanam normal $=(75 \mathrm{~cm}-20 \mathrm{~cm})$. Huruf yang sama pada kolom yang sama menunjukkan tidak berbeda berdasarkan uji Tukey pada taraf kepercayaan $95 \%$.

Note:

Legowo row arrangement $=(100 \mathrm{~cm}-50 \mathrm{~cm}) * 20 \mathrm{~cm} ;$ normal $=(75 \mathrm{~cm}-20 \mathrm{~cm})$. The same letter in the same column means no different based on the Tukey test at the 95\% confidence level

Tabel 7. Rata-rata Tinggi Tanaman, Tinggi Tongkol, Panjang Daun, Lebar Daun dan Jumlah Biji per Tongkol

Table 7. Plant height rate, ear stand height, leaf length, wide leaf and number kernels per ear

\begin{tabular}{lccccc}
\hline $\begin{array}{c}\text { Jarak Tanam } \\
\text { Plant row } \\
\text { arrangement }\end{array}$ & $\begin{array}{c}\text { Tinggi tanaman } \\
\text { Plant height }\end{array}$ & $\begin{array}{c}\text { Tinggi } \\
\text { tongkol } \\
\text { Ear stand } \\
\text { height }\end{array}$ & $\begin{array}{c}\text { Panjang daun } \\
\text { Leaflength }\end{array}$ & $\begin{array}{c}\text { Lebar daun } \\
\text { Leaf wide }\end{array}$ & $\begin{array}{c}\text { Jumlah biji per } \\
\text { tongkol } \\
\text { Kernels number } \\
\text { per ear }\end{array}$ \\
\hline $\begin{array}{l}\text { Legowo } \\
\text { Normal }\end{array}$ & $190.88 \mathrm{a}$ & $96.39 \mathrm{a}$ & $102.50 \mathrm{a}$ & $10.95 \mathrm{a}$ & $397.25 \mathrm{~b}$ \\
\hline
\end{tabular}

Keterangan : Jarak tanam legowo $=(100 \mathrm{~cm}-50 \mathrm{~cm}) * 20 \mathrm{~cm}$; jarak tanam normal $=(75 \mathrm{~cm}-20 \mathrm{~cm})$. Huruf yang sama pada kolom yang sama menunjukkan tidak berbeda berdasarkan uji Tukey pada taraf kepercayaan $95 \%$

Note : Legowo row arrangement $=(100 \mathrm{~cm}-50 \mathrm{~cm}) * 20 \mathrm{~cm} ;$ normal $=(75 \mathrm{~cm}-20 \mathrm{~cm})$. The same letter in the same column means no different based on the Tukey test at the $95 \%$ confidence level

Hasil uji korelasi Pearson menyatakan kekuatan hubungan antar peubah pengamatan secara linier. Pada umumnya karakter utama yang digunakan dalam perhitungan nilai korelasi merujuk pada produktivitas atau hasil (Saputra et al., 2017). Nilai koefisien korelasi yang positif berarti menunjukkan bertambahnya suatu karakter akan diikuti bertambahnya karakter yang berkorelasi dengan karakter tersebut, sedangkan nilai korelasi yang negative menunjukkan adanya kompetisi antar karakter (Sa'diyah et al., 2017). Hasil uji korelasi antara bobot panen biji dengan karakter agronomis lainnya pada penelitian ini menunjukkan hubungan tidak nyata. 
Koefisien korelasi antara hasil dengan karakter agronomi tertinggi diperoleh pada panjang tongkol dan tinggi tanamanya itu masing-masing $\mathrm{r}=0.40$. Korelasi yang sangat nyata dan memiliki koefisien tinggi diperoleh pada tinggi tongkol dengan tinggi tanaman $(\mathrm{r}=0.73)$. Korelasi negatif dengan hasil ditunjukkan pada peubah jumlah baris biji dan jumlah biji per baris, namun dengan nilai yang kecil dan tidak nyata dengan nilai koefisien korelasi masing-masing $(\mathrm{r}=-0.26)$ dan $(\mathrm{r}=-0.09)$.

Tabel 8. Korelasi Hasil Biji dengan Karakter Agronomis pada Perlakuan Kombinasi Dosis Pupuk dan Model Jarak Tanam Berbeda

Table 8. Yield correlation with agronomoc characters on combination of fertilizers dosage and two plant rows arrangement model

\begin{tabular}{|c|c|c|c|c|c|c|c|c|c|}
\hline $\begin{array}{l}\text { Karakter Agronomis } \\
\text { Agronmic characters }\end{array}$ & Yield & $\mathrm{X} 1$ & $\mathrm{X} 2$ & X3 & $\mathrm{X} 4$ & X5 & X6 & X7 & X8 \\
\hline $\begin{array}{l}\text { Panjang Tongkol (X1) } \\
\text { Ear length }(X 1)\end{array}$ & $0.4 \mathrm{~ns}$ & & & & & & & & \\
\hline $\begin{array}{l}\text { Diameter Tongkol } \\
\text { (X2) }\end{array}$ & $0.4 \mathrm{~ns}$ & $0.5^{*}$ & & & & & & & \\
\hline $\begin{array}{l}\text { Ear diameter (X2) } \\
\text { Jumlah Baris Biji (X3) }\end{array}$ & & & & & & & & & \\
\hline $\begin{array}{l}\text { Kernels row number } \\
\text { per ear }(X 3)\end{array}$ & $-0.3 \mathrm{~ns}$ & $-0.3 n s$ & $0.1 \mathrm{~ns}$ & & & & & & \\
\hline $\begin{array}{l}\text { Jumlah Biji per Baris } \\
\text { (X4) } \\
\text { Kernels number per } \\
\text { row }(X 4)\end{array}$ & $-0.1 \mathrm{~ns}$ & $-0.3 n s$ & $-0.4 \mathrm{~ns}$ & $-0 \mathrm{~ns}$ & & & & & \\
\hline $\begin{array}{l}\text { Bobot } 100 \text { Biji }(\mathrm{X} 5) \\
100 \text { seeds weight }(X 5)\end{array}$ & $0.2 \mathrm{~ns}$ & $0.3 \mathrm{~ns}$ & $0.5^{*}$ & $0.1 \mathrm{~ns}$ & $-0.5^{*}$ & & & & \\
\hline $\begin{array}{l}\text { Tinggi Tanaman (X6) } \\
\text { Plant height }(X 6)\end{array}$ & $0.4 \mathrm{~ns}$ & $0.5^{*}$ & $0.5^{*}$ & $-0.1 \mathrm{~ns}$ & $-0.1 \mathrm{~ns}$ & $0.5^{*}$ & & & \\
\hline $\begin{array}{l}\text { Tinggi Tongkol (X7) } \\
\text { Ear stand height (X7) }\end{array}$ & $0.3 \mathrm{~ns}$ & $0.3 \mathrm{~ns}$ & $0.5^{*}$ & $0.1 \mathrm{~ns}$ & $-0.1 \mathrm{~ns}$ & $0.5^{*}$ & $0.7 * *$ & & \\
\hline $\begin{array}{l}\text { Panjang Daun (X8) } \\
\text { Leaf length }(X 8)\end{array}$ & $0.4 \mathrm{~ns}$ & $0.6^{* *}$ & $0.5^{*}$ & $-0.2 \mathrm{~ns}$ & $-0.3 \mathrm{~ns}$ & $0.2 \mathrm{~ns}$ & $0.5^{*}$ & $0.6^{* *}$ & \\
\hline $\begin{array}{l}\text { Lebar Daun (X9) } \\
\text { Leaf wide (X9) }\end{array}$ & $0.2 \mathrm{~ns}$ & $0.3 \mathrm{~ns}$ & $0.5^{*}$ & $-0 \mathrm{~ns}$ & $-0.3 \mathrm{~ns}$ & $0.3 \mathrm{~ns}$ & $0.5 * *$ & $0.4 \mathrm{~ns}$ & $0.6 * *$ \\
\hline
\end{tabular}

Keterangan : “**”=berbeda sangat nyata; “*”=berbeda nyata; "ns”=berbeda tidak nyata pada taraf kepercayaan 95\% berdasarkan korelasi Pearson. Warna biru yang semakin pekat menunjukkan nilai $r$ yang semakin tinggi dan positif, warna merah yang semakin pekat menunjukkan nilai $r$ yang semakin negatif

Note : "**"=highly significantly different; "**"=significantly different; "tn" = non significantly different at the 95\% level of confidence based on Pearson correlation. The darker blue color indicates the higher and more positive $r$ value, the darker red color shows the increasingly negative $r$ value

\section{KESIMPULAN}

Interaksi perlakuan dosis pemupukan dengan jarak tanam menunjukkan perbedaan nyata pada peubah lebar daun. Hasil panen tertinggi pada faktor tunggal pupuk diperoleh pada kombinasi pupuk $350 \mathrm{~kg} / \mathrm{ha}$ Urea $+50 \mathrm{~kg} / \mathrm{ha} \mathrm{Za}(10.62$ ton/ha). Model jarak tanam legowo secara mandiri menunjukkan hasil $9.66 \mathrm{t} / \mathrm{ha}$ lebih tinggi dibandingkan jarak tanam $75 \mathrm{~cm} \mathrm{x}$ $20 \mathrm{~cm}$. Untuk menghasilkan jumlah biji per tongkol yang lebih banyak, maka jarak tanam $75 \mathrm{~cm}$ x $20 \mathrm{~cm}$ dapat dipilih. Model jarak tanam legowo kombinasi pupuk 350 
$\mathrm{kg} / \mathrm{ha}$ Urea $+50 \mathrm{~kg} / \mathrm{ha} \mathrm{Za}$ dapat direkomendasikan untuk menghasilkan dan bobot panen tinggi pada produksi benih F1 jagung hibrida Bima 20. Karakter agronomis tidak memiliki koefisien korelasi yang nyata terhadap hasil biji. Koefisien korelasi Pearson tertinggi diperoleh pada peubah panjang tongkol dan tinggi tanaman.

\section{DAFTAR PUSTAKA}

Apriliana, M. and M. Mustadjab. 2016. Analisis Faktor-Faktor yang Mempengaruhi Pengambilan Keputusan Petani Dalam Menggunakan Benih Hibrida Pada Usahatani Jagung (Studi Kasus di Desa Patokpicis, Kecamatan Wajak, Kabupaten Malang). HABITAT, 27(1). pp.7-13.

Arief, R., F. Koes, and A. Nur. 2013. 县 Pengelolaan Benih Sorgum. In: Sumarno, D.S. Damardjati, M. Syam and Hermanto, (eds.) Sorgum (Inovasi Teknologi dan Pengembangan). Jakarta (ID): IAARD Press; Badan Penelitian dan Pengembangan Pertanian, pp.153-.

BMKG. 2018. Analisis Kondisi 钢 Meteorologi Pada Saat Banjir Tanggal 14 Mei 2018 di Kabupaten Sidrap Sulawesi Selatan [Online].

Efendi, R. and M. Azrai. 2010. Tanggap 钢 Genotipe Jagung terhadap Cekaman Kekeringan: Peranan Akar. Jurnal Penelitian Pertanian Tanaman Pangan, 29(1). pp.1-10.

Erawati, B.T.R. and A. Hipi. 2016. 钢 Pengaruh Jarak Tanam Terhadap Pertumbuhan dan Hasil Beberapa Varietas Jagung Hibrida di Kawasan Pengembangan Jagung Kabupaten Sumbawa. In Proceedings: Prosiding Seminar Nasional Inovasi Teknologi
Pertanian Banjarbaru, 2016. Banjarbaru: Balai Pengkajian Teknologi Pertanian Nusa Tenggara Barat, pp.608-616.

Erungan, R.H., D.S. Runtunuwu, and E.E.X. Rogi. 2012. Produksi Jagung Manado Kuning Pada Jarak Tanam dan Dosis Pupuk Nitrogen Berbeda. EUGENIA, 18(3). pp.230-237.

Ikhwani, I. 2014. Dosis Pupuk dan Jarak 县 Tanam Optimal Varietas Unggul Baru Padi. Jurnal Penelitian Pertanian Tanaman Pangan, 33(3). p.188.

Irwan, A.W., A. Wahyudin, R. Susilawati, and T. Nurmala. 2005. Interaksi Jarak Tanam dan Jenis Pupuk Kandang Terhadap Komponen Hasil dan Kadar Tepung Sorghum (Sorghum bicolor [ Linn .] Moench) pada Inseptisol di Jatinangor $\mathrm{MH}$ 2004. Jurnal Kultivasi, 4(2). pp.128136.

Kementrian Pertanian. 2016. Outlook EQ Komoditas Pertanian Tanaman Pangan "Jagung." Jakarta: Pusat Data dan Sistem Informasi Pertanian, Kementerian Pertanian.

Koes, F. and Rahmawati. 2009. Pengaruh Lama Penyimpanan Terhadap Mutu Benih dan Produktivitas Jagung. In Proceedings: Prosiding Seminar Nasional Serealia, 2009. Maros, Sulawesi Selatan: Balai Penelitian Tanaman Serealia (Balitsereal), pp.283-289.

Kushartanti, E., D. Prasetianti, and S.C.B. Elyaningrum. 2019. Persepsi dan preferensi petani terhadap produktivitas jagung hibrida balitbangtan di Kabupaten Kendal. In Proceedings: Prosiding Temu 
Teknis Jabatan Fungsional Non Peneliti, 2019. Bogor: Pusat Perpustakaan dan Penyebaran Teknologi Pertanian, Kementrian Pertanian, pp.603-610.

Moser, S.B., B. Feil, S. Jampatong, and P. 住 Stamp. 2006. Effects of pre-anthesis drought, nitrogen fertilizer rate, and variety on grain yield, yield components, and harvest index of tropical maize. Agricultural Water Management, 81(1-2). pp.41-58.

Pratama, E.Y., R. Hasputri, and R.T. 住 Setiyono. 2019. Uji Daya Hasil Pada Beberapa Calon Varietas Jagung Hibrida di PT Mulya Agro Sarana. Jurnal Pertanian Presisi (Journal of Precision Agriculture), 3(2). pp.120 128.

Rahmansyah, B. and Sudiarso. 2018. 钢 Pengaruh Teknik Jajar Legowo dan Berbagai Jarak Tanam Pada Pertumbuhan dan Hasil Tanaman Jagung Bisi 16 (Zea mays identata). Jurnal Produksi Tanaman, 6(6). pp.1012-1019.

Rahmawati and S. Saenong. 2010. Mutu

尌 Fisiologis Benih pada Beberapa Varietas Jagung Selama Periode Simpan. In Proceedings: Prosiding Pekan Serealia Nasional, 2010. Maros, Sulawesi Selatan: Balai Penelitian Tanaman Serealia (Balitsereal), pp.478-485.

Sa'diyah, N., C.R. Siagian, and M. 钢 Barmawi. 2017. Korelasi dan Analisis Lintas Karakter Agronomi Kedelai (Glycine max [L.] Merrill) Keturunan Persilangan Wilis X MLG 2521. Jurnal Penelitian Pertanian Terapan, 16(1). pp.45-53.
Saputra, T.E., M. Barmawi, E. Ermawati, 顽 and N. Sa diyah. 2017. Korelasi dan Analisis Lintas Komponen Komponen Hasil Kedelai Famili F6 Hasil Persilangan Wilis X B3570. Jurnal Penelitian Pertanian Terapan, 16(1). pp.54-60.

Sayo, S., K.O. David, J.A. Omolayo, M. El Silvestro, S.F. Lawrence, O.O. Ayoola, and O.O. Adebiyi. 2017. Correlation and Path Coefficient Analysis of Top-Cross and ThreeWay Cross Hybrid Maize Populations. African Journal of Agricultural Research, 12(10). pp.780-789.

Sesay, S., D.K. Ojo, O.J. Ariyo, and S. 尌 Meseka. 2016. Genetic Variability, Heritability and Genetic Advance Studies in Top-Cross and Three-Way Cross Maize (Zea Mays L) Hybrids. Maydica, 61(2). pp.1-7.

Sirappa, M.P. and N. Razak. 2010. EQ Peningkatan Produktivitas Jagung Melalui Pemberian Pupuk N, P, K dan pupuk Kandang pada Lahan Kering di Maluku. In Proceedings: Prosiding Pekan Serealia Nasional, 2010. Maros, Sulawesi Selatan: Balai Penelitian Tanaman Serealia (Balitsereal), pp.1-10.

Srihartanto, E., S.W. Budiarti, and Suwarti. E 2013. Penerapan Sistem Jajar Legowo Jagung Hibrida Untuk Peningkatan Produktivitas di lahan Inceptisol Gunung Kidul. In Proceedings: Seminar Nasional Serealia, 2013. Maros, Sulawesi Selatan: Balai Penelitian Tanaman Serealia (Balitsereal), pp.98-103. 
Sutoro. 2012. Kajian Penyediaan Varietas 钢 Jagung untuk Lahan Suboptimal. Iptek Tanaman Pangan, 7(2). pp.108-115.

Syafruddin, S. 2016. Manajemen

县 Pemupukan Nitrogen Pada Tanaman Jagung. Jurnal Penelitian Dan Pengembangan Pertanian, 34(3). p.105.

Syafrudin, N., M. Azrai, and N. Suwarti. 到 2016. Seleksi Genotipe Jagung Hibrida Toleran N Rendah. Buletin Plasma Nutfah, 19(2). p.73.

Syuryawati, S. and F. Faesal. 2016. Kelayakan Finansial Penerapan Teknologi Budi Daya Jagung pada Lahan Sawah Tadah Hujan. Jurnal Penelitian Pertanian Tanaman Pangan, 35(1). p.71. 